\section{Central Valley leaders cautious about agricultural easements}

\author{
Alvin D. Sokolow
}

THE Central Valley is the premier agricultural region in California. But it lags far behind central coastal areas in the accumulation of agricultural easements, an increasingly popular technique for protecting farmland through voluntary landowner action. The 18-county Central Valley has far fewer established local easement programs, participating landowners and agricultural acres under easement than a group of five coastal counties from Sonoma to the north to Santa Barbara to the south. The entire Central Valley in mid-2000 contained only $15 \%(13,100$ acres $)$ of the state's total 84,000 acres under agricultural easements, as compared with $70 \%$ ( 59,000 acres) for the coastal counties.

To investigate the prospects for greater use of agricultural easements in the Central Valley, we interviewed 111 community leaders in 11 Central Valley counties, in 1999 and 2000. The respondents were county and city planning directors, leaders of county Farm Bureau organizations, agricultural commissioners, building industry leaders, agricultural bankers, land appraisers and community activists. In open-ended interviews, mostly in person and averaging about 40 minutes, we asked their familiarity with the technique, its merits, possible local applications and a range of other questions. Not all interviewees

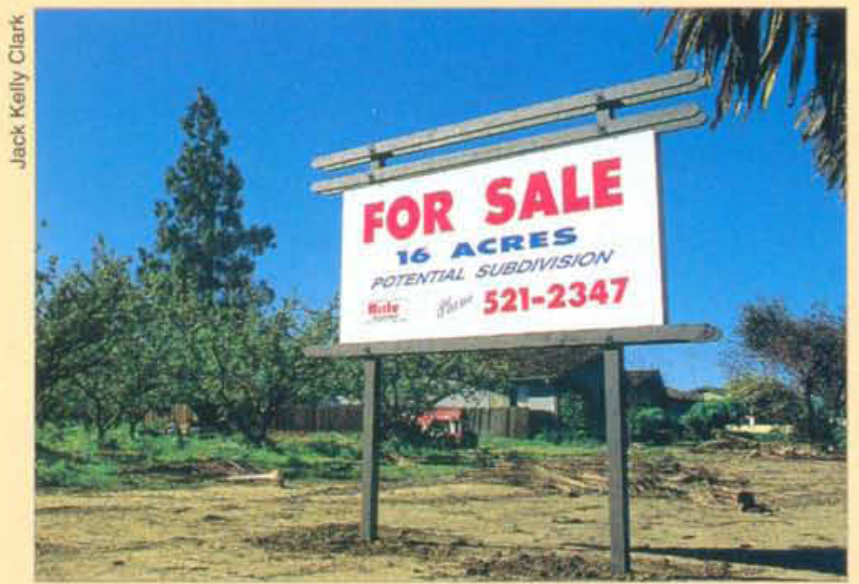

In California's agriculturally rich Central Valley, community leaders had generally positive impressions about easements but there were few enthusiastic supporters. In Patterson, land was offered for subdivision. responded to all questions.

While the results are not directly comparable to interviews conducted with landowners involved in three major easement land-trust programs in the northern Bay Area and Yolo County, the findings suggest important regional differences. Most notably, Central Valley respondents expressed more cautious views about use of easements to protect farmland.

\section{Survey synopsis}

Familiarity. About four fifths of respondents were generally familiar with the easement technique, with most reporting an elementary level of knowledge. Planners, land appraisers and agricultural commissioners tended to be the most knowledgeable, with bankers and building industry people the least.

Positive impressions. As to whether easements on farmland are a "good idea" in concept, positive responses outranked negatives 32 to 5 . But a larger number (50) said "maybe" or expressed some uncertainty, citing issues of funding, location, relation to planning tools and community support $(\mathrm{N}=87)$.

Local impact. As to whether easements are a "good idea" for respondents' particular localities, responses were positive by 51 to 34 , with another 34 indicating conditional approval $(\mathrm{N}=90)$.

Pros and cons. Benefits to landowners topped the list of advantages, while problems with location and perpetuity were tied for top disadvantages (fig. 1).

Perpetuity. There was a 19 (pro) to 15 (con) split on whether easements should last in perpetuity, with another 13 respondents having positive but cautious views $(\mathrm{N}=47)$.

Nonprofits. By a 46 to 11 margin, respondents favored nonprofit land trusts over public agencies to manage easement programs $(\mathrm{N}=57)$.
Priorities. Location in relation to urban growth was mentioned by 37 respondents as an important priority for programs acquiring easements, while 19 each cited quality of land or multiple priorities $(\mathrm{N}=75)$.

\section{Consideration of easements}

We also asked 33 farmland owners, mostly local Farm Bureau leaders, whether they would be interested in selling easements on their agricultural land. This was clearly a hypothetical question, since all but one of the interviewees had never had the opportunity to consider an easement sale. And in all but two or three cases, the farmland they owned was distant from the nearest urbanization and had virtually none of the development potential that programs frequently seek as a qualification for an easement acquisition. Nonetheless, the responses were mixed: 16 yes, 8 no, 9 maybe.

One Kings County farmer we interviewed said: "I manage 40 acres in walnuts for a family group. It's not really close to development. But some of my brothers think that there will be a shopping center out there in about 40 years, and so they're betting on the future. I don't think that's realistic. But no, we would not be interested in getting into an easement."

Another in Kern County noted: "I would have to bring the family together and say, 'Would you be interested in doing this sort of thing?' We all have our homes here. There are three of us. I'd have to get them to think about the future. Do they really want to hold on to this facility?"

\section{Positive but cautious}

In general, the Central Valley leaders were mildly positive but cautious about the merits of agricultural easements and the possibility of expanding their use in California's premier agricultural region. Few respondents rejected the technique outright. But there also were few enthusiastic supporters. A high degree of uncertainty ran through the responses, with questions raised about perpetuity and other practical issues.

In responding to our questions, many interviewees may have been constrained by limited knowledge about 
TABLE 2. Motivations cited by landowners for selling easements

\begin{tabular}{|c|c|c|c|c|c|c|c|c|}
\hline \multirow[t]{2}{*}{ Motivation } & \multicolumn{2}{|c|}{ Marin ${ }^{\bullet}$} & \multicolumn{2}{|c|}{ Sonoma } & \multicolumn{2}{|c|}{ Yolo } & \multicolumn{2}{|c|}{ Total } \\
\hline & $\#$ & $\%$ & $\#$ & $\%$ & \# & $\%$ & $\#$ & $\%$ \\
\hline Preserving land for farming & 7 & 5 & 88 & 35 & 2 & 100 & 17 & 46 \\
\hline Cash for nonfarm use & 7 & 58 & 8 & 35 & - & & 15 & 41 \\
\hline Passing land to next generation & 7 & 58 & 3 & 13 & - & & 10 & 27 \\
\hline Cash to invest in farm operations & 4 & 33 & 4 & 17 & 2 & 100 & 10 & 27 \\
\hline Settling estate problem & 3 & 25 & 6 & 26 & - & & 9 & 24 \\
\hline Cash to reduce farm debt & 3 & 25 & 5 & 22 & 1 & 50 & 9 & 24 \\
\hline Preserving land for open space & - & & 8 & 35 & - & & 8 & 22 \\
\hline No. landowners responding & 12 & & 23 & & 2 & & 37 & \\
\hline
\end{tabular}

- Marin = Marin Agricultural Land Trust; Sonoma = Sonoma County Agricultural Preservation and Open Space District; Yolo = Yolo Land Trust.

sale could help the younger family members purchase the parcel from the older generation or prepare for the transition by paying down existing farm debt or improving the farm operation. In one situation, the farm operator used the proceeds from the easement sale to secure full control of the land by buying out the ownership shares of his siblings.

Surprisingly, the permanence of a deed restriction - the issue of keeping the land in agriculture in perpetuity, essentially forever - did not discourage landowners from selling easements. However, this sample includes only participating landowners and not those who might have chosen not to sell because of this restriction. Only five respondents expressed some discomfort with the permanent nature of their easement. In fact, for the majority of landowners, perpetuity was considered an advantage because their goal was to pass the land on, undeveloped, to future generations. One respondent did argue for less-than-permanent easements because he felt they were more compatible with the economic fluctuations in agriculture.

For most of the nine landowners in the three counties who purchased their properties after the development rights had been removed, having an easement in place was considered an advantage. The principal reason, they said, is that it made the purchase more affordable. By eliminating the possibility of development, an easement in effect reduces the market value from a speculative to a farm production level.

\section{Program shortfalls}

When asked about the effectiveness and impact of the program's public goals such as slowing urbanization and preserving farmland, the great majority $(83 \%)$ of landowners stated that the programs were successful. However, they expressed some common reservations and concerns about the easement programs, including that they:

- Pay too much for easements on particular parcels.

- Acquire easements on parcels that would not be subject to development in any case

- Do little to stem the continuing loss of farmland or maintain the longterm viability of local agriculture, due to larger economic forces.

- Are too bureaucratic, have too large a staff or conduct affairs in a political manner.

- Have insufficient funds to continue easement program purchases.

- Are unsympathetic to farmers.

\section{Landowner-program relationship}

At the heart of the easement process is the relationship between the landowner and the land trust or other conservation organization that acquires the easement, whether through purchase or donation. It begins with a conversation about the possibility of a landowner entering into an easement transaction, and continues through formal negotiations over price and other terms. After acquisition, the agency periodically monitors compliance with the easement terms. Land- owners may also be involved in the organization's other activities.

We asked the 37 landowners in three counties who had sold easements to describe their easementrelated experiences with the land trust or open space district. While landowners were generally positive about their experiences, they also had specific recommendations for how the three organizations could improve their relationships with landowners. The majority of the comments centered on negotiating easement terms and the agency's ongoing monitoring of their properties.

Negotiations. Discussions between the landowner and the conservation organization usually focus on two areas: the price, and changes in the use and character of the covered parcel that the easement will allow. One area of landowner concern was the time it took in some cases to negotiate and complete a transaction. Various factors can complicate and lengthen the process: disagreements over price that require more than one appraisal, landowner consultations with attorneys or consultants, or delays until the land trust receives the funds to close the deal.

One landowner in Yolo County, who purchased a parcel after the easement was in place, had no idea that he wouldn't be able to build a home because of specific restrictions named in the deed. Landowners suggested that programs should seek ways to clarify and expedite easement negotiations and terms. They felt that if programs provided complete information upfront, and made sure purchasers understood the easement terms including the conditions of monitoring and use restrictions, misunderstandings and negative feelings would be reduced.

The most frequent sticking point seemed to be the construction of additional residences or farm outbuildings. Landowners wanted the flexibility to house family members or farmworkers. Several landowners expressed the opinion, when asked if they would participate again, that they would revise their easement deeds to provide more flexibility for family 


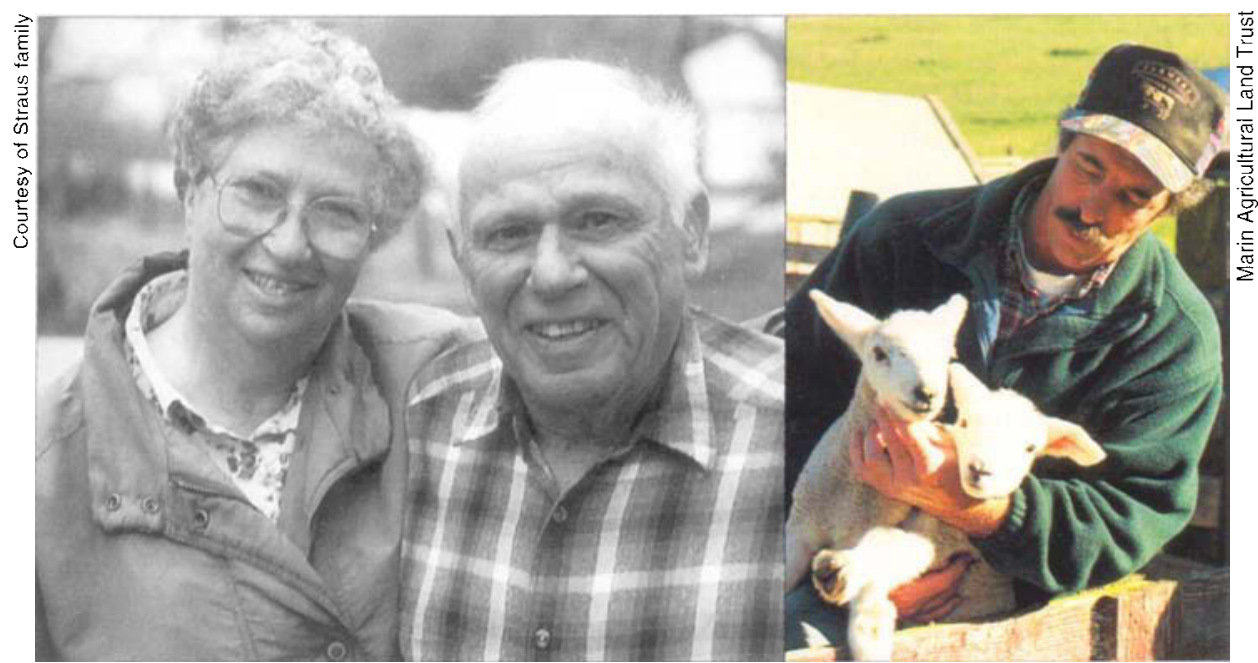

Uitimately, landowners must make a sometimes difficult, personal decision about whether to sell an easement. In Marin County, some who did include: left, Marin Agricultural Land Trust co-founder Ellen Straus and her husband William, of Straus Family Creamery, an organic dairy on Tomales Bay; and right, sheep rancher Bill Jensen of Tomales.

housing. This included the location, size and number of buildings allowed. While the conservation organization generally tries to tailor these terms as closely as possible to the expressed needs of individual landowners, we found that some organizations were more lenient than others in defining the parameters of an easement.

Monitoring. Contact between the landowner and the conservation organization does not end at completion of the easement transaction. The easement terms require that the relationship continue indefinitely to ensure that landowners adhere to the restrictions that have been placed on the property. Program staff or volunteers periodically monitor the uses and conditions of the property, typically through annual site checks and other forms of data collection.

Monitoring of easements was controversial among some of those we interviewed. Of the 33 respondents who commented on the subject, 14 reported negative experiences or perceptions of the process. Landowners do not like intrusions on their property regardless of whether they agreed to them on paper. Landowners suggested that programs monitor easement-restricted parcels as a cooperative rather than adversarial process. They suggested that the personnel responsible should be sensitive to local circumstances, be knowledgeable about local agricul- tural practices and provide more practical assistance with improving land management practices.

\section{Statewide applications}

Easements are unquestionably a flexible tool for advancing the indifarmland owners, as suggested by the owners who sold easements in three California counties. They liked the economic and conservation benefits of the transactions, and were largely positive about the negotiations and other experiences with conservation agencies. Nonetheless, while the easement programs seemed to work for farmers in the northern Bay Area counties and Yolo County, it's not clear that they will appeal to landowners in other parts of the state and, in particular, the agriculturally rich Central Valley. This region differs from the three counties we surveyed in having a greater diversity of agricultural crops, no coastal zones to justify the protection of farmland as open space, less apparent community support for land preservation programs and perhaps a more conservative agricultural community.

E. Rilla is Community Development Advisor and County Director, UC Cooperative Extension, Marin County. vidual, family and business goals of
What landowners say about their conservation easements

\section{Compiled by Ellen Rilla}

"It allowed us to buy the dairy and keep the land in agricultural production. It would have been very difficult otherwise. Now I plan to keep this in agricultural production and hand it down to future generations."

- Nicasio farmers who used easement funds to purchase leased dairy

"The price of preservation is high for those who retain ownership of the land. A big problem we face is inheritance tax. The land has escalated in value way beyond what we're able to pay. I'm 60 years old and in a position to be both inheriting it and passing it on. I would have had to sell the farm, and that's the last thing I want to do." - Marin landowner

"We didn't have any debt on the property. We looked at the easement in terms of the money it would bring. I haven't done anything more with it than draw interest. It's a long-term investment gain, or maybe we can use it for houses (on the land) for the children." - Sonoma landowner

"More farm properties would get carved up upon death of the owners because of estate issues. The long-term effect of this program is to keep properties intact." - Sonoma landowner

"The easement program gets around the zoning, which can be changed by the board of supervisors. Nothing is forever with zoning - it can be changed on a whim. The easement is a forever thing."

- Yolo landowner

\section{References}

Bowers D. 2001. Annual survey of local programs. Farmland Preservation Report (Street, MD) 11(9):1-6.

Elconin P, Luzadis VA. 1997. Evaluating Landowner Satisfaction with Conservation Restrictions. SUNY College Environ Sci and Forestry (Syracuse, NY). Montpelier, VT: Vermont Land Trust.

Maynard LJ, Kelsey TW, Lembeck SM, Becker JC. 1998. Early experience with Pennsylvania's agricultural conservation easement program. J Soil Water Conserv 53(2): 106-12.

Rilla E, Sokolow AD. 2000. California Farmers and Conservation Easements: Motivations, Experiences and Perceptions in Three Counties. UC Agricultural Issues Center, California Farmland and Open Space Policy Series, Research Paper 4. $49 p$

Sherman RL, Milshaw S, Wagner RC, Freedgood J. 1998. Investing in the Future of Agriculture: The Massachusetts Farmland Protection Program and the Permanence Syndrome. Northhampton, MA: American Farmland Trust. $75 \mathrm{p}$. 